\title{
Potentiality of Tourism and Prospect in Jamunakhadi Simsar Area of Jhapa district
}

Manamaya Mishra*

\begin{abstract}
Abatract
This paper entitled "Potentiality Tourism and Prospect in Jamunkhadi Simsar and Tourism" area of Jhapa District, Nepal" is to analyze the potentialities of tourism in this area. Jamunkhadi is one of the most scenic tourist destinations in Jhapa district. It is a land of natural scenery, the rich biodiversity, peaceful environment, ethnic diversity, the rich and diverse culture which attract visitors. The aims of the paper are to identify the prospects, potentiality and promote tourism in this area. The universal sample is Surunga VDC. The local people, hotel owner, domestic visitors and tourism experts, government service holders were the sample respondents and the sample size is only 53 for the study. The data collection method was on both primary and secondary sources. The primary data collected from the structured and semi structure questionnaire by interview schedule and key informants interview also done.

There is high potentiality of tourism in Jamunkhadi because it has numerous sightseeing spots, tourism interest places such as the lake, the jungle, the open lane, picnic spot, the mini zoo, the rubber processing center etc. There are many other attractive places around Jamunkhadi Simsar and Tourism Area such as the Mai river and bridge, Domukha, the Mai Mandir, Arjundhara Dham, Satasi Dham, Dhanuskoti Dham, tea gardens etc. It is found that most tourists spend 3 or 4 hours and no tourists spend night in the spot. Generally the visitors are domestic and they spend 200 to 1000 rupees during their stay in this area. The number of foreign tourist is found very low according to the local people. Local people were found very much interested and devoted for promoting tourism in the study area but there seems lack of co-ordination among the government authorities and local promoters and also lack of fund. Jamunkhadi deserves high potentiality of becoming one of the best rural tourism destinations of the country.
\end{abstract}

Keywords: Potentiality, prospective, Tourism, Promote and Visitors.

\section{Background}

It is possible to grow it up due to availability of natural beauty, historical and cultural monuments, arts, architecture, festival, floras and fauna diversities which can attract various types of tourist. Rural tourism is the tourism which takes place in the country side which can be promoted not only attracting foreign people but also local people who are called internal tourists.

* Mrs. Mishra is a Lecturer at tha Department of Population, T.U., Patan Multiple Campus. Patan Dhoka. 
Tourism in Nepal is faced with 3 major challenges. First, to increase tourist inflows into the country and then divert that flow to various sites with tourism potential as opposed to the present pattern where visitors are concentrated in urban areas or in a few well known and well - warn destinations. Secondly, to attract quality tourists who could better contribute to the local and national economy while contributing to conservation of nature and natural resources. This can be done by developing eco-tourism projects that could increase the flow of quality visitors to various parts of the country. Thirdly, to diversity tourism products and services by expanding activities such as mountain biking and bungee jumping that are not yet fully explored and developed in Nepal (MOPE, 2004).

Nepal has the most favourable conditions for visitors and the sojourn of foreigners. Everybody agrees that its tourist potential is immense and varied, as the country after a great choice of attractive possibilities which always answer the renewed demand of modern international travellers. Foreign visitors want novelty and Nepal which has so long kept out of the traditional currents of world events, constitutes a new and special attraction. Owing to its very isolation, its remote character has an unrivalled charm and appeal which is irresistible (Satyal, 2004).

A newly introduced tourist destination of eastern Nepal JAMUNKHADI SIMSAR \& TOURISM AREA is located at Jamunbari, Surunga VDC; ward No. 2 \& 3 Jhapa. The area of wetland is 40 hector land. Sometimes ago, it was the community forest area which became the victim of deforestation. Here different casts of people live among them 114 households are very poor, 134 poor, 209 lower class family and 149 HHs are middle class family. The climate is hot and the plants here are Sal, Karma, Sisau, Botdhamero, Chilaune, Chap, Harro, Barro, Amala, or many other local plants and trees. Different types of indigenous birds and other various birds are found here (CFUG Profile). Here are found snake, fish, Garor, Goro, tortoise, Andhabam, boaconstractor (Python), monkey, jackle, fox, wild pig, deer, Lokharke, Dhendu etc. The tourism spot has been aimed to be promoted with the various water fun, fisheries, and green cottage picnic spot for tourists and income opportunities for the local people which can be strong backbone of rural development.

Jamunkhadi Simsar \& Tourism Area is one of the places which are not developed yet. It is popular for its wetland area which lies $1.5 \mathrm{~km}$ north from Mahendra Highway. People visit the area from different places. It is necessary to develop the tourism potentiality to attract the internal as well as external tourists for more than 1 day. Tourism sectors should provide all things and materials with various tourist needs and wants. Only the natural beauty isn't enough to fulfill the desire of the tourist. Tourism needs 7As such as attraction, accessibility, accommodation, affinity activities amenities and actors. Innumerable places 
like Jamunkhadi Simsar \& Tourism Area are not introduced as tourism spots in Nepal due to lack of publicity and sound accommodation.

The objectives of this paper are as follows:

- to find out tourism prospects and potentiality of this area

- To examine the natural and cultural resources to promote tourism this area.

- To analyze the activities of CFUG to promote tourism in this area.

\section{Methodology}

The Jamunkhadi Simsar or Jamunkhadi Wetlands is a wetlands conservation project in the Kankai municipality of Jhapa District, in eastern Nepal. It was created to be developed as a tourist destination in Wards 2 and 5 of Surunga VDC (which are now the Dandagau area of Kankai), within the community forest. It lies about a kilometer away from the EastWest Highway and occupies an area of about 10 hectares of the 25-hectare community forest. ${ }^{[1]}$ Originally, it included two ponds named after the rivers Ganga $\underline{\text { (Ganges) }}$ and Jamuna, but due to lack of protection, Ganga no longer exists and currently only Jamuna remains. Jamuna pond is a tourist attraction. There is boating and fishing on the pond. Wild animals such as the python, bear, sambar, and porcupine are protected in this area. This is descriptive cum explanatory research design. Rural tourism is a new concept to attract external and internal tourists. Jamunkhadi is one of the rural areas where rural and eco-tourism is strongly possible. Jamunkhadi, wetland area, rare animals and birds, boating, jungle scenario, open lane picnic spot, Chulachuli are the beautiful attractions here. Therefore, Jamunkhadi Simrar and Tourism Area is selected for the study.The total 53 sample of the total population is taken from different categories who have been involved in tourism development directly or indirectly. Out of total 53 sample, 12 (22.7\%) local people, 30 ( $56.6 \%$ ) domestic tourists, 6 (11.3\%) hotel owners and 5(9.4\%) tourism experts are chosen for the study by non-random sampling method because the population was infinite. The respondent s of local people, domestic tourist \& hotel owners is taken by convenient sampling method and the tourism experts are chosen by purposive sampling method.

The primary data have been collected through structured questionnaire. Interview and direct apparition also have been applied to collect primary data. The tourism experts, government service holders and the committee members have been chosen for key information. The major issues of discussion have been focused on tourism prospect and potentiality in the study area with nine persons whose profession is in tourism sector. Structure and semistructure questionnaire schedule have been prepared for the collection of primary data related to the objectives of the study. Collected data have been encoded, edited and presented in appropriate formats in a meaningful way using computer. The data are presented in table and analyzed accordingly. 


\section{Results}

\section{Age \& Gender of the Local Respondents}

Out of total sampled respondents, 22.70 percent are from local people using convenient sampling method. Altogether 12 respondents are local. Out of them 50 percent are male and 50 percent are female. Twelve percent respondents are below 20 years of aged while the maximum numbers of respondents are age group 20 to 40 years which was 33.33 percent and 40 to 60 years of age group 8.3 percent are came to visit of this area.

\section{Marital Status of the Local Respondents}

The marital status of the respondents was divided into 2 categories married and unmarried. The highest i.e. 75.50 percent respondents are married and 24.50 percent respondents are unmarried. More married and newly married couples are visited this tourism area.

\section{Occupation of the Local Respondents}

Most of the respondents are involved in agricultural sectors. Farmers and students (both) are found 25 percent and hotel and business each are 16.7 percent. The least number of respondents is in each service and social service that is 8.33 percent.

\section{Visitors Age and Occupation}

Around 73.33 percent visitors are below the age of 30 years followed by 20 percent between 31 to 45 years and 6.7 percent between 45 to 60 years age group. It is found that mostly young couples use to visit the spot.

The visitors' occupation found in the study area during study period is found farmers, students, businessmen, teacher and housewife. The visitors are found 41.7 percent farmers, 33.3 percent student, 8.3 percent business man, 8.3 percent teacher $\& 8.3$ percent housewife. Each among them 83.3 percent $1^{\text {st }}$ time visitors \& 16.7 percent $t$ are $2^{\text {nd }}$ time visitors. It shows that most of the visitors are rural poor people and their children.

\section{Purpose of Visit}

Tourists seemed to visit Jamunkhadi for different purpose. The purposes according to the visitors were entertainments, sight-seeing \& religious cultural. Almost half (50\%) visitors visit the place for Entertainment, 40 percent visit for sigh seeing \& 10 percent visitors visit the place for religious purposes. It shows that the spot is famous for entertainment. During leisure time people can visit the spot.

\section{Domestic Tourist}

During the field survey, domestic tourists who visit Jamunkhadi Simsar Area were asked about different topics. Most of them gave more preference to the nature beauty of the lake, jungle \& the open lane, the big python, different birds etc. similarly, the purpose of visit was found mostly sightseeing and entertainment. 
Among the visitors, 50 percent are male and 50 percent are female visitors. No visitors hold night in the spot. According to them the reasons are the spot is new \& they are local people. Few of them have no home near but they use to stay at relatives' house. Some visitors who visit the spot feel climate problem, lack of accommodation \& the area is small.

\section{Type of Visitors}

There are found domestic visitors most. According to the respondents view, most of domestic visitors are from eastern development region. Visitors are from India (Sikkim \& Darjeeling). Also use to visit the area. Very few foreigners visit the study area. The visitors stay for few hours in the study area. Local people say that there are no paying guests they have kept.

Table 1: Types of Visitors in Percentage in the Respondents View

\begin{tabular}{|c|c|c|}
\hline \multirow{2}{*}{ No. of respondents } & \multicolumn{2}{|c|}{ Types of visitors in percentage } \\
\cline { 2 - 3 } & Domestic & Foreigners \\
\hline 10 & 93 & 7 \\
\hline 2 & 90 & 10 \\
\hline
\end{tabular}

Source: Field Survey, 2017.

Most of the visitors are domestic tourist. Most of the respondents have said that 93 percent domestic visitors and only 7 percent foreign visitors visit there. Thus it is found that the spot is the destination of domestic tourist. There is found domestic tourism.

\section{Flow of Tourists}

The tourist flow is the great prospect of tourism. The researcher has found the tourist flow in Jamunkhadi Simsar and according to local people more than 50 visitors visit Jamunkhadi Simsar and Tourism Area per day. But during peak seasons the number is up to 5000-6000 per day for different purposes. Such flow of the tourist in a new rural destination can be taken as the symptom of a successful potential tourism destination in near future.

\section{Expenditure of Visitors}

Expenditure of tourists plays an important role for the promotion of tourism in any place. More expenditure of the tourists will be more income to the rural people. The expenditure pattern of the tourists visiting Jamunkhadi Simsar \&Tourism Area is given below.

Table 2: Expenditure of Visitors in the Study Area

\begin{tabular}{|l|l|l|}
\hline Expenditure (Rs) & No. of Respondents & Percent \\
\hline
\end{tabular}




\begin{tabular}{|l|c|c|}
\hline Below 200 & 15 & 50 \\
\hline $200-500$ & 12 & 40 \\
\hline $500-1000$ & 3 & 10 \\
\hline 1000 above & 0 & 0 \\
\hline Total & 30 & 100 \\
\hline
\end{tabular}

Source: Field Survey, 2017.

Most of the visitors i.e. 50 percent spend below Rs. 200/- followed by 40 percent spend Rs. 200/- to Rs. 500/-. Only 10 percent visitors spend Rs. 500/- to Rs. 1000/-. No visitors are found who spend more than Rs. 1000/- in the study area. It shows the low expenditure of the visitors in the study area which can present either the respondents' low economic status or the spot's poor tourist products.

\section{Influencing Factors for Tourism in the Study Area}

Jumunkhadi Simsar \& Tourism area is a beautiful place in the point of view of tourism. It is popular in domestic tourism for sightseeing, bio-diversity, nature beauty and picnic spot. According to the field survey in the study area the influencing factor for tourism in Jamunkhadi Simsar \& Tourism Area is given below.

Table 3: Distribution of Visitors by Influencing Factor of Tourism

\begin{tabular}{|c|c|c|c|c|c|c|c|}
\hline \multirow[t]{2}{*}{ Influencing Factors } & \multicolumn{6}{|c|}{ No of Respondents by Priority } & \multirow[t]{2}{*}{ Total } \\
\hline & $1^{\text {st }}$ & $2^{\text {nd }}$ & $3^{\text {rd }}$ & $4^{\text {th }}$ & $5^{\text {th }}$ & $6^{\text {th }}$ & \\
\hline Good climate & 1 & 6 & 3 & 5 & 5 & 10 & 30 \\
\hline Sightseeing & 10 & 10 & 2 & 3 & 5 & - & 30 \\
\hline Good facilities & 2 & 5 & 3 & 6 & 4 & 10 & 30 \\
\hline Bio-diversity & 9 & 8 & 5 & 6 & 2 & - & 30 \\
\hline Extra culture & 4 & 5 & - & 3 & 6 & 12 & 30 \\
\hline Natural beauty & 10 & 8 & 4 & 4 & 3 & 1 & 30 \\
\hline
\end{tabular}

Source: Field Survey, 2017.

The maximum numbers of respondents give high priority to natural beauty, sightseeing \& bio-diversity. In the field survey, the priority is given to the important factors for the tourism potentialities in the study area. Very few visitors of the spot come to enjoy extra culture, good facilities and good climate.

\section{Activities of CFUG to Promote Tourism in the Study Area}

The CFUG has made important short term plan \& long term plan for the development of the wetland \& tourism area. It has applied to the tourism board for the support of tourism development. The local tourism body has asked help from various ministry, tourism board \& NPC for the proper development of the spot. 
The management of Drinking water, toilet, rest-house or others, deer park, children park, proper habitat for rare animals, enlargement of Simsar area, eating sitting for tourists, library, plantation of rare plants \& medicinal herbs \& compound protection bar are in the short term plan of the committee.

The construction of pitched road from Mahendra highway to the wetland area, management of football play-ground in the wetland, construction of swimming pool and development of the next lake to the east of Jamunkhadi, construction of guest house, keeping process to enlist in Ramsar area, construct horse-way within jungle area and develop the Ramite Dada as tourist destination situated in Chure to the north of the spot and supply water in Simsar area maintaining old drinking tank \& pipeline collecting water from Chure hill are enlisted in the long term plan of the CFUG.

The CFUG has initiated the tourism development program in the spot since 2065/10/16. They want to develop the spot as 'Jamunkhadi Simsar and Tourism Area' for the protection of Natural resources and bio-diversity.

The aims of CFUG in developing the spot as tourist destination are conservation of biodiversity, development of eco-tourism, development of rural tourism, creation of local job opportunities, uplift of rural livelihood, making the group 'an example of the nation in prosperity through collective local efforts'

\section{Results}

Most of the people are involved in agriculture. The total 53 sample sizes of the respondents was taken from 4 different categories who have been involved in tourism profession directly or indirectly by using simple random sampling method. Out of total sample size, 22.7 percent local people, 56.6 percent domestic tourists, 11.3 percent hotel owners and 9.4 percent tourism experts. The number of visitors in Jamunkhadi is high. The high number of tourist flow to Jamunkhadi shows the great prospect of tourism development. The other great prospect of tourism development in the study area is the support of local people \& their contribution. Most of the employees in the hotel are in the age group of (20-40) years that is 80 percent. Out of total visitors 73.33 percent are found in the age group of below 30 years followed by 20 percent from the age group of (31-45) years and 6.7 percent from the age group of (46-60) years. The 50 percent visitors visit Jamunkhadi for the purpose of entertainment followed by 40 percent sightseeing and 10 percent for religious/cultural purposes. Most of the respondents have given $1^{\text {st }}$ priority to sightseeing, natural beauty \& bio diversity. Natural beauty, good climate, sight seeing, good facilities, bio-diversity, and extra culture are the other influencing factors of the visitors. The locals, tourism experts, Government service holders of the spot are found quite eager to develop the spot as tourism destination. The VDC has committed to activate Surunga VDC level tourism development 
committee. The CFUG has made important short term plan \& long term plan for the development of the spot. The committee has asked help for the development of the spot \& applied to the tourism board, various ministries and NPC. The tourism board, various ministries \& NPC have not shown keen interest for the development of the spot according to the CFUG members.

\section{Conclusion}

According to the study on prospects of tourism it can be concluded that the spot is favorable for tourism development. There seems the great flow of tourist. The status of hotels seems poor. The spot is able to provide earning opportunities to the local people in the hotels. The length of stay of the visitors is found too short which seems to be lengthened. Though, the visitors spend few in the spot, due to the great flow of the tourist, the earning seems high. The great influencing factors of tourist are natural beauty sightseeing and biodiversity. Good facilities are seen to be improved there. The extra culture of the local people is seen to be developed.

The natural beauty, biodiversity, religious spots, water fun, the rubber processing Centre, the jungle, the zoo etc. are the lovely attractions for the tourists. The visitors, who love natural beauty and extra religious cultural activities, come and visit the place. Tourists of different purposes can be attracted by the natural and cultural aspects of the study area.

The involved institutions are found little bit helpful in the efforts made by the CFUG. The VDC has supported the effort only by enlisting in the VDC policy. Tal Development Centre and DFO has provided, financial aid which seems inadequate. The contribution of local people and their support seems strong backbone of tourism development in the study area. The national level stakeholders like NPC, tourism board and the ministries are seen not helpful in the effort. The CFUG is found playing the most important role for the development of the study area by bringing short term plan, long term plan and taking important aims.

As a conclusion of the study it can be said that Jamunkhadi Simsar \& Tourism Area has a high potentiality of tourism as in other destinations of Nepal. The tourist flow can prove it very well. Though the spot is newly started to be known as tourism destination it has been found to attract great number of tourist. The spot has become the tourism destination of young couples, farmers, students, teachers, businessmen, social, service holders etc. for different purposes. The destination has become able to provide job opportunity to the rural local people. The rural people's life standard can be uplifted. The natural environment \& biodiversity are being protected. Thus the tourism development in Jamunkhadi can be helpful in rural poverty alleviation \& in solving climate change problem. In near future it can earn money by carbon trade which can be the extra benefit to the rural area. Due to the 
lack of co-ordination among concerned agencies, lack of fund, poor infrastructure and poor marketing strategies, the development of tourism in Jamunkhadi has been found in shadow. So, efforts from the concerned stakeholders are necessary in multi-field in promoting tourism in Jamunkhadi Simsar and Tourism Area.

\section{References}

MOCTCA (2002). Nepal Tourism Statistics, Government of Nepal, Ministry of Culture, Tourism and Civil Aviation, Kathmandu.

NPC (2010). Three Year Plan Approach Paper (2010/11-2012/13)

Shree Jamunbari CFUG, (2066/067 B.S.). Independent Audit Report -2066/067, Community Forest User Group, Jhapa.

Shree Jamunbari Community Forest User Group, (2064 B.S.) Community Profile-2064, Community Forest User Group, Jhapa.

Surunga VDC, $18^{\text {th }}$ Budget \& Program (F.Y.2067/68 B.S.)

WTO (1994). Framework for the Collection and Publication of Tourism Statistics, Madried. World Tourism Organization. 